
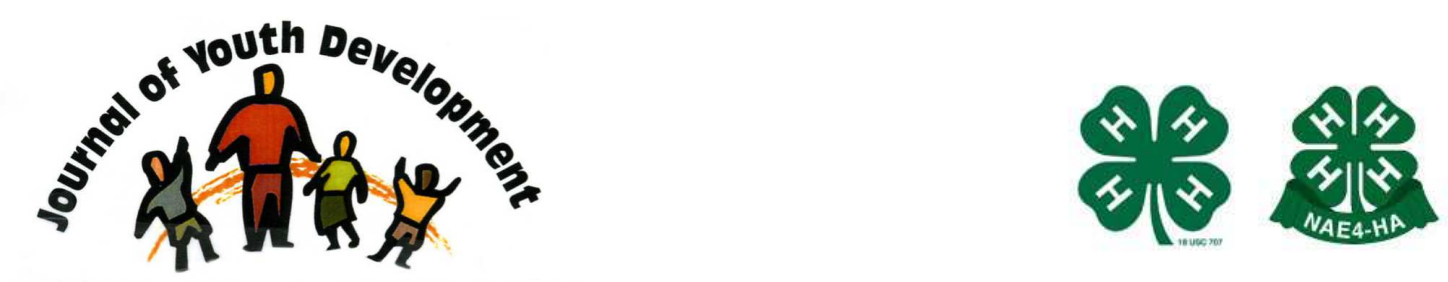

Bridging Research \& Practice

\title{
Interdependence: Ninth and Newest Critical Element for 4-H Positive Youth Development
}

\author{
Kirk A. Astroth \\ Arizona 4-H Youth Development \\ University for Arizona \\ Tucson, AZ \\ kastroth@u.arizona.edu
}




\section{JOURNAL OF YOUTH DEVELOPMENT \\ bridging research and practice

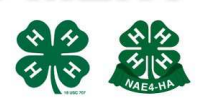

Volume 9, Number 3, Fall 2014

Article 140903FA001

\section{Interdependence: Ninth and Newest Critical Element for 4-H Positive Youth Development}

Kirk A. Astroth

University of Arizona

Abstract: For the past 15 years, a list of eight critical elements has provided a strong foundation for articulating the positive youth development focus of 4-H programs and efforts. Now it is time to revisit this list and update the critical elements for positive youth development. Interdependence is proposed as a $9^{\text {th }}$ critical element that should be included. Research is cited for the importance of this element that was not included in the original list in 1998, and a call is made for a national think tank to update the critical elements.

\section{Introduction}

More than 15 years ago, a group of researchers was called together and assembled in Tucson at the University of Arizona to begin a process which would have major impacts on the 4-H program both nationally and locally. In December 1997, forty-five people from twenty-three states met in Tucson, Arizona, to discuss and design a National Impact Assessment of the 4-H Youth Development Program (National 4-H Impact Assessment Project, 2001, p. 8). The purpose of this work was to clearly identify the critical elements of positive youth development as supported by research that could be measured and quantified. It was exciting work, and the energy in the room was palpable because for the first time as a system, we were embarked on an effort to distill out the essential and critical aspects that led to positive youth development outcomes.

Out of this meeting, several working groups were appointed to conduct additional groundsetting work before a national assessment could be conducted. As a result, a smaller group of Extension specialists met in Kansas City in 1998 to identify the most important elements of positive youth development. Called the "Critical Elements Working Group,"

...this group's task was framed in the research question "What positive outcomes in youth, adults, and communities result from the presence of critical elements in a 4-H experience." The group reviewed the basic and applied research on characteristics of effective programs for youth development. Emphasis was placed on using existing empirical research on what impacts positive youth development. Another criterion used 
by the group was relevancy to $4-\mathrm{H}$ that could be communicated to colleagues, researchers and volunteers. From this process, eight elements critical to youth development emerged (p. 8):

The eight elements identified at this time were:

- A positive relationship with a caring adult

- A safe environment-physically and emotionally

- Opportunity for mastery

- Opportunity to value and practice service to others

- Opportunity for self determination

- An inclusive environment

- Opportunity to see oneself as an active participant in the future

- Engagement in learning

The Critical Elements Working Group was chaired by Stephen Carlson of the University of Minnesota, and included Kirk A. Astroth of Montana State University; Laura Merek, University of Connecticut; Ina Lynn McClain (Linville) of the University of Missouri; Anne Rumsey of the University of Idaho; and Gary Gerhard of Kansas State University. The task of this group was to "collect research on critical elements of 4-H and to decide which to include" in a possible national impact study. The second task "was to look for measures of these elements. This group made their findings available to the Outcomes Group in March 1998" (National 4-H Impact Assessment Project, 2001, p. 53).

In 2002, the National Research Council and Institute for Medicine came out with their now wellknown "blue book" titled Community Programs to Promote Youth Development (Eccles, \& Gootman, 2002). This report was the result of a 2-year project to integrate and evaluate a wide range of science related to adolescent development. From their work, they identified 8 features of positive youth development settings (p. 117):

- Physical and psychological safety

- Appropriate structure

- Supportive relationships

- Opportunities to belong

- Positive social norms

- Support for efficacy and mattering

- Opportunities for skill building

- Integration of family, school and community efforts

Obviously, the 4-H Critical Elements and the National Research Council's features of positive youth development settings share some similarities. In fact, the National 4-H Leadership Trust worked to help the youth development field understand the underlying alignment of these elements by comparing them as shown in Table 1. 
Table 1

A comparison between 4-H Critical Elements of Positive Youth Development and the National Research Council's Features of Positive Youth Development Settings

\begin{tabular}{|c|c|}
\hline $\begin{array}{l}\text { Critical Elements Essential to Positive } \\
\text { Growth and Development-4-H }\end{array}$ & $\begin{array}{l}\text { Features of Settings That Help Facilitate } \\
\text { Positive Development -National Research } \\
\text { Council }\end{array}$ \\
\hline A positive relationship with a caring adult. & $\begin{array}{l}\text { Opportunities to experience supportive } \\
\text { relationships and to have good emotional and } \\
\text { moral support. }\end{array}$ \\
\hline Safe physical and emotional environment. & $\begin{array}{l}\text { Physical and psychological safety and security. } \\
\text { Structure and limits that are developmentally } \\
\text { appropriate and that recognize adolescents' } \\
\text { increasing social maturity and expertise. } \\
\text { Opportunities to be exposed to positive morals, } \\
\text { values, and positive social norms. }\end{array}$ \\
\hline Opportunities to master skills and content. & $\begin{array}{l}\text { Opportunities for skill building, including learning } \\
\text { how to form close, durable human relations with } \\
\text { peers that support and reinforce healthy } \\
\text { behaviors, as well as to acquire the skills } \\
\text { necessary for school success and successful } \\
\text { transition into adulthood. }\end{array}$ \\
\hline $\begin{array}{l}\text { Opportunities for self-determination, decision- } \\
\text { making and goal setting. }\end{array}$ & $\begin{array}{l}\text { Opportunities to be efficacious, to do things that } \\
\text { make a real difference and to play an active role } \\
\text { in the organizations themselves. }\end{array}$ \\
\hline Opportunities to be an active, engaged learner. & $\begin{array}{l}\text { Opportunities to be efficacious, to do things that } \\
\text { make a real difference and to play an active role } \\
\text { in the organizations themselves }\end{array}$ \\
\hline An inclusive atmosphere. & Opportunities to feel a sense of belonging. \\
\hline \multicolumn{2}{|l|}{ Opportunities to practice service for others. } \\
\hline \multicolumn{2}{|l|}{ A positive connection with the future. } \\
\hline & $\begin{array}{l}\text { Strong links between families, schools, and } \\
\text { broader community resources. }\end{array}$ \\
\hline
\end{tabular}

Each of these lists was derived from an extensive review of essentially the same youth development research literature, although the "Critical Elements" list was done three years earlier than the "Features of Settings" list. While the language differs slightly, the content is substantially the same. As you can see from the table above, the "Critical Elements" list generated by 4-H includes two items not included in the National Research Council "Features of Settings" list:

- Opportunities to practice service for others

- A positive connection with the future

The "Features of Settings" list includes one item that was not part of the National 4-H Impact Study:

- Strong links between families, schools, and broader community resources.

\section{Further Revisons}

In 2005, 4-H National Headquarters director of youth development, Cathann Kress, distilled the eight critical elements defined by 4-H into just four essential elements-Belonging, Independence, Generosity and Mastery-or what is often referred in short-hand as BIG-M. The 
simplification of the 8 critical elements was one way to help people remember the core components of positive youth development without having to remember all eight critical elements, although the 8 are still subsumed under the 4 essential elements (Kress, 2009).

Table 2

Essential Elements (Kress, 2009)

\begin{tabular}{|l|}
\hline Belonging \\
\hline$\bullet \quad$ Positive relationship with a caring adult \\
\hline$\bullet \quad$ An inclusive environment \\
\hline Mastery \\
\hline$\quad$ Engagement in Learning \\
\hline Opportunities for Mastery \\
\hline Independence \\
\hline O Opportunity to see oneself as an active participant in the future \\
\hline Generosity \\
\hline Opportunity to value and practice service for others \\
\hline
\end{tabular}

\section{Updating the Critical Elements}

In my view, it is time to revisit and update the list of critical elements for positive youth development. Like Howard Gardner's "multiple intelligences" that have expanded from the original 7 to now include 8 forms of learning, based on what we continue to learn about human development (Armstrong, 2003; Gardener, 2012), it is time for us to re-consider our list. We should ask if we have fully captured the requisite skills young people need to transition for the second decade of life into adulthood As Gardener observed, his work was iterative and constantly evolving as he re-visited his own work every so often. He was fortunate, he says, to have had an opportunity to lay out his theory and "revisit the chessboard at decade intervals" (p. 13).

Those of us who are faculty at the land-grant universities should take the same approach with 4-H's critical elements. In fact, I believe it is time to add a ninth element-interdependence. Let me try and make the case here for why interdependence needs to be included in our list of critical elements of positive youth development.

As a member of the National Recognition Task Force in the mid-1990's, I advocated hard for expanding our traditional model of recognition to include cooperation as a $5^{\text {th }}$ way to recognize the achievements of young people. In 1996, that 5-part model was released to the National 4-H system and has been used ever since as a guide for local educators and program directors (National 4-H Council, 1996).

Interestingly enough, Fetsch and Yang found only two articles in the Journal of Extension referencing empirical data on children related to cooperation from 1975 to 2001 . In addition, these studies included only small numbers of participants. At the same time, though, they referenced a meta-analysis of 122 studies (Johnson, Maruyama, Johnson, Nelson, \& Skon, 1981) which found that cooperation often resulted in superior end results: 
Cooperation is considerably more effective than interpersonal competition and individualistic efforts in promoting achievement and productivity, and; cooperation without intergroup competition seems to promote higher achievement and productivity than cooperation with intergroup competition (p. 53).

Reporting on their own study with 4-H and non-4-H members, the authors found that cooperation was a better strategy for building self-concept than competition and that 4-H programs needed to include more cooperative learning strategies in the future (Fetsch, \& Yang, 2002). While young people liked both competition and cooperation, the latter was more effective at developing personal strengths.

The importance of interdependence and associational relationships also goes back much further in our history and culture. Alexis de Tocqueville, that astute observer of early American life, in particular noted American's tendency to work together and form groups. De Tocqueville was especially intrigued by the number of associations and community groups in American as compared to Europe. In his book about his trip to the U.S. called Democracy in America, de Tocqueville credited our sense of community and mutual support as a key distinguishing feature for why democracy flourished in America. "In no country in the world has greater advantage been derived from association nor has this powerful instrument of action been applied to a wider variety of objectives than in America" (2003, p. 220).

Wallace Stegner, one of the giants of American and Western literature was one of the first people to argue that our past was built, not upon rugged individualism, but rather on mutual interdependence. In The Sound of Mountain Water ${ }_{\perp}$ Stegner observed that: "When it (the West) fully learns that cooperation, not rugged individualism, is the quality that most characterizes and preserves it, then it will have achieved itself and outlived its origins. Then it has a chance to create a society to match its scenery" (1980, p. 38).

Later, Robert Putnam, in his seminal work called Bowling Alone (2000), observed that "Community has warred incessantly with individualism for preeminence in our political hagiology" (p. 24). As Putnam persuasively presents in chapter after chapter, social bonds are one of the most important predictors of happiness and well-being, and when a community loses these connections, the community becomes impoverished and weakened. Without strong social bonds, a community's quality of life is lowered, crime rates increase, social maladies increase and health declines.

Moreover, Putnam argues, our myth of rugged independence as a foundation for the development of the nation are just that-myths. "Our national myths often exaggerate the role of individual heroes and understate the importance of collective effort....Paul Revere's alarm was successful only because of networks of civic engagement in the Middlesex villages. Towns without well-organized local militia, no matter how patriotic their inhabitants, were AWOL from Lexington and Concord" (p. 24).

Meg Wheatley (1999) described the three components of self-organizing capacity of organizations-organizational identity, information flow and interdependent relationships. Allen and Morton (2006) further delineated the skills set for interdependent relationships to include building teamwork, building partnerships and managing conflict. As Wheatley points out, "Order emerges as elements of the system work together, discovering each other and together inventing new capacities" (p. 111). Organizational development requires nurturing interdependent relationships. 
Despite the importance of interpersonal relationships, Sue Johnson, author of Hold Me Tight (2008), describes a 2006 National Science Foundation study that found that the number of individuals in people's circle of confidants was declining. To Johnson, this is disturbing news because close personal relationships, ones in which people are interdependent, are so critical to physical and emotional health. She noted that "science for all fields is telling us very clearly that we are not only social animals, but animals who need a special kind of close connection with others, and we deny this at our peril" (p. 24).

"We need emotional attachments with a few irreplaceable others to be physically and mentally healthy-to survive" (p. 15). According to her research, "Today it is widely accepted that children have an absolute requirement for safe, on-going physical and emotional closeness and that we ignore this only at great cost" (p. 20). Yet, "our culture's established social and psychological ideas of adulthood: that maturity means being independent and self-sufficient" ( $p$. 21).

While all of these previous works persuasively make the case for the importance of interdependence, there is also a plethora of research which supports the evidence cited above. Over 750 research studies (Johnson, 2003) conducted during the past 11 decades on the relative merits of cooperative, competitive, and individualistic efforts have demonstrated that superior performance and achievement results from cooperative strategies which stress the importance of mutual interdependence (your success=my success).

In addition, a group of researchers used meta-analysis to review 148 independent studies comparing the effectiveness of different goal structures for supporting early adolescents' achievement and positive peer relationships (Roseth, Johnson, \& Johnson, 2008). Spanning more than 80 years of research and involving more than 17,000 early adolescents in more than 10 countries, the results are a persuasive argument for the positive effects of mutual interdependence. Higher achievement and more positive peer relationships were positively associated with cooperative rather than competitive or individualistic goal structures. In addition, though, cooperative goal structures correlated with a positive relation between achievement and positive peer relationships.

\section{Interdependence: the $9^{\text {th }}$ Critical Element}

Let's be clear-interdependence is not just the critical element of "belonging" dressed up in different clothes. Belonging is about group identity and having a feeling of a group or member affiliation. Like a uniform, insignia, handshakes, or lore, belonging is more about a badge of group identity-such as "we are all Rotarians." But it is not about mutual interdependence. Belonging does not begin to scratch the surface of the critical interdependence of people to work toward common goals or purposes.

While there is much to be said for cultivating a sense of autonomy in young people, there are equally persuasive reasons for fostering a sense of mutual interdependence and mutual reliance. Interdependence, unlike belonging, is about how our fates and futures are inextricably intertwined. Interdependence is an expression of how we produce better results and greater outcomes when we share expertise and work together in cooperative and collaborative ways. It encompasses the synergy that can occur when multiple minds get together and face an issue or problem so that the end result is better than anything anyone could have accomplished alone. 
In a 4-H context, what are some examples of interdependence? What does interdependence look like?

An easy example is the 4-H club. Clubs can only succeed when they figure out that their success depends on everyone working together toward the same goal-fund-raising, doing community service, sharing leadership or through civic action. Much of what goes on in the 4-H environment is actually far more about interdependence than it is about independence. Project clubs, camps, field trips, even team demonstrations and something as basic as livestock judging which takes the best scores of 3 individuals for a team score. Individual scores are used but so are team scores. Once one starts to look closely at the 4-H experience, interdependence seems intuitive and a natural element of positive youth development. Upon reflection, it is surprising that this element of positive youth development settings was overlooked in the initial review of research.

The late Dr. Martin Luther King, Jr. understood this concept of interdependence quite well and spoke about it in his "I've Been to the Mountaintop" speech given the day before he was shot in Memphis, Tennessee. King recalled the story of the Good Samaritan and challenged us to think about why the priest and the Levite did not stop along the Jericho road to help a seriously injured man while the Good Samaritan did. Certainly the road was dangerous and robberies were common. There were a lot of reasons not to stop and provide aid to the injured manafter all, he may be faking it or he may have accomplices hiding nearby who would rob the travelers. Both the priest and the Levite asked themselves: "If I stop, what will happen to me?" But when the Good Samaritan came along, King recalled, he reversed the question and asked himself: "If I do not stop to help this man, what will happen to him?"

Now that is an example of interdependence.

\section{Next Steps}

Without a doubt, interdependence is a critical element in positive youth development. It is time to update our list of critical elements. And who knows? There may be others. Land-grant university faculty and researchers are in an ideal position to help us keep this work current and up-to-date. No one else can take on this task.

Given the strong research base for including interdependence as the ninth critical element of 4-H positive youth development, what is next? The author suggests several steps.

1. A national think tank should be convened to re-examine the latest research and review the current list of critical elements to determine if they need updating and expansion.

2. State 4-H Program leaders should establish a standing committee on research to ensure a focus on emerging research related to positive youth development. This committee should meet during the regular annual face-to-face meeting of the 4- $\mathrm{H}$ program leaders, and by conference call at other times.

3. A new model of 4-H positive youth development should be disseminated, based on this work, to ensure that the new information is promulgated far and wide.

4. Training should be conducted to help 4-H professionals and volunteers understand the importance of interdependence as a critical element of positive youth development. 
With these efforts, we can ensure that our focus on the essential elements of positive youth development remains up-to-date and inclusive of the latest research and knowledge about human development.

\section{References}

Allen, B.L., \& Morton, L.W. (2006). Generating self-organizing capacity: Leadership training practices and needs in non-profits. Journal of Extension, [On-line], 44(6) Article 6FEA6. Available online at: http://www.joe.org/joe/2006december/a6.php

Armstrong, T. (2003). You're smarter than you think: A kid's guide to multiple intelligences. Minneapolis, MN: Free Spirit Publishing.

Community Programs to Promote Youth Development. (2002). Washington, DC: National Research Council. National Academy Press, Washington, D.C.

de Tocqueville, A. (2003). Democracy in America and two essays on America. New York: Penguin Books.

Eccles, J., \& Gootman, J.A. (eds). (2002). Community programs to promote youth development. Washington, DC: National Academy Press.

Fetsch, R.J., Robert F.J., \& Yang, R.K. (2002). The Effect of Competitive and Cooperative Learning Preferences on Children's Self-Perceptions: A Comparison of 4-H and Non-4-H Members. Journal of Extension. [On-line), 40(3) Article 3FEA5. Available at: http://www.joe.org/joe/2002june/a5.php

Gardner, H. (2012). MI after twenty years. Retrievable on-line at:

http://howardgardner01.files.wordpress.com/2012/06/mi-after-twenty-years2.pdf

Johnson, D.W. (2003). Social interdependence: interrelationships among theory, research, and practice. American Psychology, 58(11):934-45 (November).

Johnson, D.W., Maruyama, G., Johnson, R., Nelson, D., \& Skon, L. (1981). Effects of cooperative, competitive, and individualistic goal structures on achievement: A meta-analysis. Psychological Bulletin, 89(1), 47-62.

Kress, C. (2009). Essential elements of 4-H youth development PPT presentation. Washington, DC: National 4-H Headquarters, CSREES, USDA.

National 4-H Impact Assessment Project. (2001). National 4-H Impact Assessment Project. Tucson: University of Arizona. [On-Line] Available at: http://4h.ucanr.edu/files/13698.pdf

National 4-H Council. (1996). Recognition in youth programs: Helping young people grow. Chevy Chase, MD: National 4-H Council.

Prepared and Engaged Youth, the National 4-H Impact Assessment Project, Families, 4-H and Nutrition, State Research, Education and Extension Service, United States Department of Agriculture, Cooperative Washington, D.C. (2001). 
Putnam, R.D. (2000). Bowling Alone: The Collapse and Revival of American Community. New York: Simon \& Schuster.

Roseth, C.J., Johnson D.W., \& Johnson, R.T. (2008 March). Promoting early adolescents' achievement and peer relationships: the effects of cooperative, competitive, and individualistic goal structures. Psychological Bulletin, 134(2):223-46.

Stegner, W. (1980). The Sound of Mountain Water. Lincoln, NE: University of Nebraska Press.

Wheatley, M.J. (1999). Leadership and the new science: Discovering order in a chaotic world. San Francisco: Berrett-Koehler Publishers.

(C) Copyright of Journal of Youth Development $~$ Bridging Research and Practice. Content may not be copied or emailed to multiple sites or posted to a listserv without copyright holder's express written permission. Contact Editor at: patricia.dawson@oregonstate.edu for details. However, users may print, download or email articles for individual use. 